\title{
IMPLEMENTASI MODEL PEMBELAJARAN PROBLEM BASED LEARNING UNTUK MENINGKATKAN MOTIVASI BELAJAR MATEMATIKA SISWA SMK
}

\author{
RR KP Rahayuningsih \\ SMK Negeri 2 Purworejo \\ E-mail: yayukwibowo28@gmail.com
}

\begin{abstract}
ABSTRAK
Penelitian ini bertujuan untuk meningkatkan motivasi belajar matematika pada siswa kelas XII AKL-3 SMK Negeri 2 Purworejo tahun ajaran 2019/2020 melalui model pembelajaran Problem Based Learning. Penelitian ini merupakan penelitian tindakan kelas (PTK) yang dilaksanakan dalam dua siklus. Teknik pengumpulan data dilakukan menggunakan instrumen angket, dan lembar observasi. Motivasi siswa dilihat dengan menggunakan lembar observasi dan angket. Untuk mengetahui tingkat keberhasilan dari setiap siklus, analisis data pada penelitian ini berpedoman pada analisis deskriptif dengan teknik persentase. Hasil penelitian ini menunjukkan adanya peningkatan motivasi belajar siswa dari siklus I ke siklus II sebesar 8,86\% dengan kategori tinggi. Sedangkan peningkatan prestasi belajar ditandai dengan bertambahnya siswa yang nilainya mencapai kriteria ketuntasan minimal secara keseluruhan. Pada siklus I sebesar $64,5 \%$ atau sebanyak 20 siswa mencapai kriteria ketuntasan minimal. Pada siklus II terjadi peningkatan siswa yang mencapai nilai ketuntasan minimal sebesar 80,65\% atau sebanyak 25 siswa. Jadi dapat disimpulkan bahwa implementasi model pembelajaran Problem Based Learning dapat meningkatkan motivasi dan prestasi belajar matematika siswa kelas XII AKL-3 SMK Negeri 2 Purworejo tahun ajaran 2019/2020
\end{abstract}

Kata Kunci: motivasi belajar, prestasi belajar matematika, problem based learning

\section{PENDAHULUAN}

Tujuan pembelajaran matematika salah satunya adalah pemecahan masalah yang memegang peranan cukup penting dalam pembelajaran matematika. Suherman (2003) dalam Prayanti, dkk (2014:2) mengungkapkan bahwa pemecahan masalah merupakan bagian dari kurikulum matematika yang sangat penting karena dalam proses penyelesaiannya siswa dimungkinkan memperoleh pengalaman, menggunakan pengetahuan serta keterampilan yang telah dimiliki untuk diterapkan pada pemecahan masalah. Pemecahan masalah perlu diajarkan di Sekolah Menengah Kejuruan (SMK). Seperti yang dijelaskan oleh Ninik, dkk ( 2014 : 61 ) bahwa "SMK adalah lembaga pendidikan yang membekali siswa dengan keterampilan sesuai dengan bidang yang dipilihnya dan mempersiapkan siswa untuk terjun ke dunia kerja. Dalam proses 
pemecahan masalah, siswa harus menggunakan pengetahuan matematika, kemampuan bernalar dan komunikasi, serta sikap yang baik terhadap matematika. Hal inilah yang dapat melatih siswa untuk terampil dalam menyelesaikan masalah yang dihadapi dalam kehidupan sehari-hari".

Menurut Oon Sen Tan (2004: 7), ketika peserta didik mempelajari sesuatu dan diberikan masalah, hal tersebut memberikan siswa tantangan untuk berfikir lebih dalam. Diperlukan model pembelajaran berbasis masalah memfasilitasi siswa untuk menjadi belajar secara aktif dalam menyelesaikan masalah, hal ini diungkapkan oleh Barbara dan Younghoon (Tan, 2004: 168). Albanese dan Mitchel (Tan, 2004:7) memperkuat bahwa dibandingkan dengan model pembelajaran konvensional, lebih baik digunakan model pembelajaran berbasis masalah yang mampu mengkonstruksi konsep dan mengembangkan keterampilan proses. Sebagai solusi atas permasalahan diatas, digunakan model pembelajaran berbasis masalah sebagai suatu model pembelajaran yang menggunakan masalah.

Menurut Dutch (dalam Amir 2009: 21) Problem Based Learning merupakan metode instruksional yang menantang siswa agar belajar untuk belajar, bekerja sama dalam kelompok untuk mencari solusi bagi masalah yang nyata masalah ini diguakan untuk mengingatkan rasa keingintahuan serta kemampuan analitis dan inisiatif atas materipelajaran. PBL mempersiapkan siswa untuk berpikir kritis dan analisis dan untuk mencari dan menggunakan sumber pembelajaran yang sesuai. Pendapat tersebut diperkuat oleh Pusdiklatkes (2004) bahwa belajar berdasarkan masalah atau PBL adalah suatu proses pembelajaran yang diawali dari masalah-masalah yang ditemukan dalam suatu lingkungan pekerjaan. PBL adalah lingkungan belajar yang didalamnya menggunakan masalah untuk belajar. Masalah diajukan sedemikian rupa sehingga para pembelajar menemukan kebutuhan belajar yang diperlukan agar mereka dapat memecahkan masalah tersebut.

Faktor lain selain ketrampilan guru dalam menggunakan variasi model dalam pembelajaran yang juga sangat berpengaruh dalam keberhasilan pembelajaran adalah motivasi belajar siswa. Motivasi belajar menjadi aspek yang sangat penting yang dapat mengimbang ketrampilan guru dalam mengajar sehingga keberhasilan dapat tercapai 
dalam pembelajaran. Motivasi belajar dan ketrampilan guru memilih model pembelajaran adalah dua hal yang saling berpengaruh, jika salah satu diantaranya tidak maksimal maka hasil yang diperolehpun kurang maksimal pula. Seringkali siswa kurang termotivasi dalam pembelajaran matematika dikarenakan model pembelajaran yang dipakai guru terlalu membosankan atau monoton. Hal ini akan mengakibatkan siswa enggan untuk memperhatikan guru, malas mengerjakan tugas bahkan siswa malas untuk mempelajari suatu topik atau suatu bahasan tertentu. Hal ini dapat menghalangi siswa untuk mendapatkan nilai maksimal dalam mata pelajaran terutama mata pelajaran matematika.

Motivasi dari dalam diri siswa adalah suatu modal terbesar untuk mendapat nilai maksimal dalam mata pelajaran. Perpaduan antara ketrampilan guru menggunakan model pembelajaran dan motivasi dari dalam diri siswa akan menghasilkan peningkatan prestasi belajar khususnya prestasi belajar matematika. Oleh karena itu diperlukan model pembelajaran yang variatif dancara untuk memotivasi siswa agar motivasi siswa naik dan siswa menjadi antusias dalam mengikuti pembelajaran matematika dan pada akhirnya memperoleh hasil yang maksimal. Tujuan yang ingin dicapai dalam penelitian ini adalah untuk meningkatkan motivasi dan prestasi belajar siswa pada pembelajaran matematika kelas XII AKL-3 SMK Negeri 2 Purworejo melalui implementasi model Problem Based Learning.

\section{METODE PENELITIAN}

Penelitian ini termasuk Penelitain Tindakan Kelas (PTK). Pengumpulan data pada penelitian ini melalui observasi dan kuisioner untuk mengetahui motivasi dalam belajar serta data nilai pre test dan post test untuk mengetahui prestasi belajar siswa. Menurut Kemmis dan Taggart (Rochiati Wiriaatmaja, 2006: 66-67), Penelitian Tindakan Kelas memiliki empat tahap dalam satu siklus. Tahapan tersebut ialah (1) Plan (perencaaan), (2) Actuating (tindakan), (3) Observe (pengamatan), (4) reflect (refleksi). 


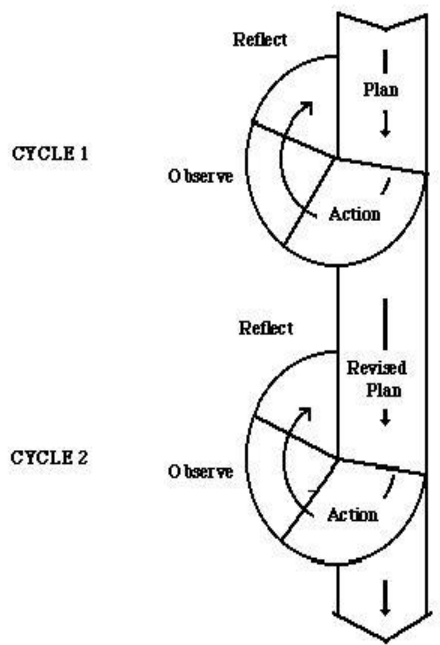

Gambar 1. Skema tahapan pelaksanaan pembelajaran pada PTK.

Berikut ini tahapan Penelitian Tindakan Kelas yang akan dilaksanakan di kelas XII AKL-3 SMK Negeri 2 Purworejo Tahun Pelajaran 2019/2020.

1. Siklus 1

a. Planning (perencanaan)

Pada tahap perencanaan, peneliti menyusun rencana pembelajaran yaitu Rencana Pelaksanaan Pembelajaran (RPP), Kuisioner (angket), Instrumen tes, dan instrumen penilaian.yang disesuaikan dengan masalah yang dihadapi peserta didik di dalam kelas.

b. Actuating (Pelaksanaan tindakan) dan Observing (Pengamatan)

Pada tahap pelaksanaan tindakan, peneliti melaksanakan pembelajaran menggunakan model Problem Based Learning yang diharapkan mampu menumbuhkan kemandirian dan meningkatkan kemauan siswa dalam mengikuti pembelajaran matematika.

c. Reflecting (refleksi)

Refleksi dilakukan untuk mengetahui kekurangan selama pembelajaran berlangsung. Dengan mengetahui kekurangan selama proses pembelajaran, diharapkan guru mampu memperbaiki proses pembelajaran selanjutnya untuk meningkatkan keberhasilan dalam belajar siswa. Perbaikan proses pembelajaran dapat dilakukan pada siklus selanjutnya yaitu siklus II. 
2. Siklus II

Pelaksanaan siklus II hampir sama pelaksanaannya pada siklus I. Pelaksanaan siklus Ilini adalah perbaikan dari siklus sebelumnya. Pada siklus II ini diharapkan kesalahan ataupun kekurangan yang terjadi pada siklus sebelumnya telah diperbaiki ataupun disempurnakan sehingga dapat berjalan lebih baik yang nantinya akan meningkatkan keberhasilan belajar siswa.

Untuk memperoleh data, peneliti menggunakan 3 teknik yaitu :

1. Observasi

Peneliti melakukan pengamatan kepada peserta didik selama pelaksanaan pembelajaran bekerjasama dengan guru mata pelajaran matematika.

2. Angket / Kuisioner

Kuesioner pada penelitian dalam bentuk skala sikap model Likert yang bertujuan untuk mengetahui motivasi siswa terhadap pembelajaran matematika.

3. Tes Tertulis

Tes diberikan sebanyak dua kali, pertama adalah pre-test yang berfungsi untuk mengetahui kemampuan awal siswa sebelum pembelajaran menggunakan model Problem Based Learning. Kedua adalah post-test yang berfungsi untuk mengetahui kemampuan akhir setelah siswa diberi perlakuan dengan model pembelajaran Problem Based Learning sehingga dapat diketahui perbedaan prestasi belajar siswa setelah pemberian variasi belajar dengan model pembelajaran Problem Based Learing.

\section{HASIL PENELITIAN DAN PEMBAHASAN}

Penelitian berlangsung selama dua pertemuan dalam dua siklus.

\section{Siklus I}

Pembelajaran matematika dilaksanakan mengunakan model Problem Based Learning. Adapun kegiatan yang dilakukan pada siklus I adalah sebagai berikut :

1. Tahap Perencanaan (Planning)

Pada tahap perencanaan, kegiatan yang dilaksanakan yaitu Menyusun Rencana Pelaksanaan Pembelajaran (RPP); Menyiapkan beberapa instrumen penelitian sepertii soal pre test, post test, angket, lembar observasi, power point bahan diskusi; Menyiapkan perlengkapan untuk penyampaian materi seperti power 
point; dan Menyiapakan lembar kegiatan kelompok.

2. Tahap Pelaksanaan Tindakan (actuating)

Pada tahap pelaksanaan tindakan, peneliti melaksanakan desain pembelajaran yang dirancang sebelumnya. Kegiatan inti dimulai dengan siswa berkelompok yang beranggotakan empat siswa. Lalu guru mulai menampilkan masalah berupa contoh dalam keseharian. Selain itu, guru juga memberikan masalah dalam bentuk artikel mengenai integral dan contoh soal dan penyelesaian yang dibagikan kepada setiap kelompok. Tugas siswa adalah berdiskusi mengenai kaitan permasalahan yang ada kemudian menganalisis penyebab serta cara mengatasinya. Siswa juga diminta memberikan contoh lain yang serupa dalam kehidupan sehari-hari. Setelah semua kelompok menyelesaikan tugasnya, semua kelompok menyampaikan hasil diskusinya. Salah satu siswa menyampaikan hasil diskusi kelompok kemudian kelompok lain memberikan tanggapan. Begitu seterusnya hingga semua kelompok menyampaikan hasil diskusinya. Setelah semua kelompok memaparkan hasil diskusi, guru mulai menampilkan materi pokok mengenai integral yang dapat membantu siswa memahami dan menyimpulkan pembelajaran. Tak lupa juga guru menjelaskan maksud dalam setiap isi slide yang ada.

Setelah selesai kegiatan inti, guru membagikan soal post test untuk mengukur kemampuan siswa setelah melakukan pembelajaran menggunakan model Problem Based Learning.

Tahap Pengamatan (observing)

Tahap pengamatan dilakukan peneliti pada saat proses pembelajaran berlangsung. Dalam tahap ini, pengamatan yang dilakukan meliputi dua variable yaitu motivasi dan prestasi belajar. Berikut adalah data dari pengamatan tersebut:

Tabel 1. Hasil Observasi Motivasi Belajar Siswa Siklus 1

\begin{tabular}{clcc}
\hline No & Indikator Motivasi Belajar & Skor & Persentase \\
\hline 1 & Ketekunan dalam belajar & 75 & 60,48 \\
2 & Ulet menghadapi kesulitan & 78 & 62,90 \\
3 & Adanya dorongan dan kebutuhan dalam belajar & 78 & 62,90 \\
4 & Adanya hasrat keinginan untuk berhasil & 75 & 60,48 \\
\hline Jumlah & 306 & 246,76 \\
Rata-rata skor Motivasi & 76,5 & 61,69 \\
\hline
\end{tabular}


Tabel 1 diperoleh dari jumlah perhitungan nilai dari 4 pernyataan yang telah disiapkan sebelumnya. Skor maksimal dalam setiap pernyataan bernilai 4 . Berdasarkan tabel 1, keseluruhan indikator masuk kedalam kategori sedang (50,01\%-70,00\%). Secara keseluruhan, skor rata-rata dari hasil observasi motivasi belajar peserta didik menunjukan angka 61,69\%, sehingga masuk dalam kualifikasi sedang.

Berdasarkan data di atas, peneliti menilai tindakan pada siklus I belum dapat mencapai kriteria keberhasilan yang diharapkan yakni skor rata-rata masuk dalam kualifikasi motivasi tinggi, sehingga dikatakan belum berhasil dan akan dilanjutkan pada siklus II.

Tabel 2. Hasil Angket Motivasi Belajar Siswa Siklus I

\begin{tabular}{lcccc}
\hline No & Kategori & Rentang Nilai & Frekuensi & Persentase \\
\hline 1 & Sangat Tinggi & $76,8 \leq x<96$ & 1 & 3,125 \\
2 & Tinggi & $57,6 \leq x<76,8$ & 22 & 71,875 \\
3 & Sedang & $38,4 \leq x<57,6$ & 8 & 25,00 \\
4 & Rendah & $19,2 \leq x<38,4$ & 0 & 0 \\
5 & Sangat Rendah & $0 \leq x<19,2$ & 0 & 0 \\
\hline
\end{tabular}

Tabel 2 menunjukan hasil angket motivasi belajar siswa. Persentase kategori sangat tinggi mencapai 3,125\% dengan jumlah siswa sebanyak 1 orang. Persentase kategori tinggi mencapai pada 71,875\% dengan jumlah siswa sebanyak 22 orang. Sedangkan Persentase kategori netral mencapai 25\% dengan jumlah siswa sebanyak 8 orang. Jika dilihat secara keseluruhan, maka dapat disimpulkan bahwa rata-rata persentase masuk pada kategori Tinggi. Berdasarkan analisis di atas, meski sudah masuk dalam kategori tinggi, peneliti memutuskan untuk melanjutkan tindakan pada siklus II, dikarenakan pada observasi yang dilakukan belum menunjukan hasil yang diharapkan.

Tabel 3. Persentase Nilai Pretest dan Posttest Peserta Didik Siklus I

\begin{tabular}{lcccc}
\hline $\begin{array}{c}\text { Kategori } \\
\text { Nilai }\end{array}$ & \multicolumn{2}{c}{ Pretest } & \multicolumn{2}{c}{ Post test } \\
\hline Nilai $<78$ & 29 & 93,5 & 11 & 35,5 \\
Nilai $\geq 78$ & 2 & 6,5 & 20 & 64,5 \\
\hline Jumlah & $\mathbf{3 1}$ & $\mathbf{1 0 0}$ & $\mathbf{3 1}$ & $\mathbf{1 0 0}$ \\
\hline
\end{tabular}


Terdapat peningkatan frekuensi/ jumlah peserta didik yang nilainya $\geq 78$ pada pre test dan post test. Pada saat pre test, peserta didik yang nilainya $\geq 78$ sebanyak 2 anak atau $6,5 \%$, sedangkan pada post test peserta didik yang nilainya $\geq 78$ sebanyak 20 anak atau 64,5\%. Sehingga peningkatannya sebesar $58 \%$ atau sebanyak 18 anak, dan sebaliknya nilai yang < 78 mengalami penurunan sebanyak 58\%. Sehingga dapat dilihat bahwa adanya pembelajaran kooperatif dengan teknik Problem Based Learning dapat meningkatkan prestasi belajar peserta didik kelas X1I AKL-3. Namun belum dapat dikatakan berhasil karena persentase belum mencapai kriteria ketuntasan yaitu sebesar $80 \%$ atau sebanyak 25 peserta didik mendapat nilai $\geq 78$.

3. Refleksi

Data di atas menunjukan rata-rata skor motivasi baik dari lembar observasi maupun angket masing-masing $61,69 \%$ dan $71,875 \%$. Skor pada angket tersebut sudah masuk dalam kategori tinggi $(57,6 \leq x<76,8)$. Untuk prestasi belajar, hasil pre test dan post test menunjukan peningkatan. Namun peningkatan tersebut belum memenuhi kriteria ketuntasan yang diharapkan yaitu sebanyak $80 \%$ peserta didik atau 25 anak memiliki nilai minimal 78. Berdasarkan data di atas, dapat dikatakan tindakan pada siklus I belum berhasil. Sehingga peneliti, observer dan guru melakukan refleksi agar pada siklus II hasilnya akan lebih baik jika dibandingkan dengan siklus I.

Pada siklus II terlebih dahulu peserta didik akan diberi pengarahan tentang kegiatan apa saja yang akan dilakukan pada saat pembelajaran. Pembelajaran yang bertujuan untuk meningkatkan motivasi dan prestasi belajar mereka perlu ditanamkan dengan jelas dan perlu juga adanya motivasi dan pemberian semangat dari guru untuk menimbulkan antusiasme peserta didik dalam pembelajaran. Pemberian semangat juga perlu disampaikan pada semua tahap kegiatan, baik pada saat guru menjelaskan materi, pada saat peserta didik mengerjakan lembar kegiatan, berdiskusi secara berkelompok dan lain-lain. Sehingga diharapkan pembelajaran akan lebih santai, manyenangkan namun tetap mengacu pada tujuan yang hendak dicapai. Sehingga motivasi dan prestasi peserta didik dapat meningkat. 


\section{Siklus II}

1. Tahap Perencanaan (planning)

Seperti pada siklus I, kegiatan yang dilaksanakan dalam perencanaan.

2. Tahap Pelaksanaan Tindakan (actuating)

Pada tahap pelaksanaan tindakan, peneliti melaksanakan desain pembelajaran yang dirancang sebelumnya dengan perbaikan-perbaikan dari siklus sebelumnya. Guru membagikan soal pre test kepada siswa untuk mengetahui kemampuan awal siswa pada siklus kedua ini. Kegiatan inti dilakukan sama dengan siklus I. Namun, pada siklus kedua ini, beberapa siswa telah aktif dalam menanggapi guru ketika guru memberi penjelasan. Setelah guru selesai memberikan materi, guru melanjutkan dengan pemberian post test.

Tahap Pengamatan (observing)

Tabel 4. Hasil Observasi Motivasi Belajar Siklus II

\begin{tabular}{clcc}
\hline No & \multicolumn{1}{c}{ Indikator Motivasi Belajar } & Skor & Persentase \\
\hline 1 & Ketekunan dalam belajar & 89 & 71,78 \\
2 & Ulet menghadapi kesulitan & 91 & 73,38 \\
3 & Adanya dorongan dan kebutuhan dalam belajar & 90 & 72,58 \\
4 & Adanya hasrat keinginan untuk berhasil & 91 & 73,38 \\
Jumlah & 361 & 291.12 \\
Rata-rata skor Motivasi & 90,25 & 72.78 \\
\hline
\end{tabular}

Tabel 4 diperoleh dari jumlah perhitungan nilai dari 4 pernyataan yang telah disiapkan sebelumnya. Skor maksimal dalam setiap pernyataan bernilai 4. Pada pernyataan 1, mengenai ketekunan dalam belajar diperoleh jumah skor seberar 89, kemudian dibagi dengan jumalah maksimal skor yang dapat diperoleh sebesar 124 dan dikali $100 \%$ maka menghasilkan persentase sebesar $71,78 \%$. Untuk pernyataan ke2, jumlah skor yang diperoleh sebasar 91 dengan hasil sebesar 73,38\%. Untuk pernyataan ke3, jumlah skor yang diperoleh sebesa 90 sehingga hasil yang diperoleh sebesar 72,58\%. Pada pernyataan ke 4, jumlah skor yang diperoleh sebesar 91 dengan hasil 73.38\%. Berdasarkan tabel 10, dapat dilihat bahwa semua indikator mencapai kualifikasi tinggi (70,01\%- 80,00\%). Rata-rata skor hasil observasi mencapai kualifikasi yang diharapkan yakni kualifikasi tinggi yaitu sebesar $72,78 \%$. Sehingga dapat dikatakan pembelajaran tersebut dapat mencapai kriteria 
ketuntasan yang diharapkan.

Tabel 5. Hasil Angket Motivasi Belajar Siswa Siklus 2

\begin{tabular}{rlccc}
\hline No & Kategori & Rentang Nilai & Frekuensi & Persentase \\
\hline 1 & Sangat Tinggi & $76,8=x<96$ & 14 & 45,16 \\
2 & Tinggi & $57,6=x<76,8$ & 12 & 38,70 \\
3 & Sedang & $38,4=x<57,6$ & 5 & 16,14 \\
4 & Rendah & $19,2=x<38,4$ & 0 & 0 \\
5 & Sangat Rendah & $0=x<19,2$ & 0 & 0 \\
\hline
\end{tabular}

Jika dilihat secara keseluruhan, skor rata-rata dari angket motivasi pada siklus II sudah mencapai kriteria ketuntasan yang diharapkan yakni masuk dalam kualifikasi motivasi sangat tinggi dengan jumlah peserta didik hampir separuh dan dan tinggi. Hanya ada 5 orang yang masuk pada kategori netral. Hal ini sejalan dengan hasil observasi yang menunjukan adanya peningkatan. Sehingga dapat dikatakan bahwa pelaksanaan pembelajaran dengan model Problem Based Learning dapat dikatakan berhasil dan diklasifikasikan dalam kategori sangat tinggi dan tinggi.

Tabel 6. Persentase nilai pre test dan post test peserta didik pada Siklus 2

\begin{tabular}{lcccc}
\hline \multicolumn{1}{c}{ Kategori } & \multicolumn{2}{c}{ Pre test } & \multicolumn{2}{c}{ Post test } \\
\multicolumn{1}{c}{ Nilai } & Frekuensi & $\%$ & Frekuensi & $\%$ \\
\hline Nilai $<78$ & 21 & 67,74 & 6 & 19,35 \\
Nilai $\geq 78$ & 10 & 32,26 & 25 & 80,65 \\
Jumlah & $\mathbf{3 1}$ & $\mathbf{1 0 0}$ & $\mathbf{3 1}$ & $\mathbf{1 0 0}$ \\
\hline
\end{tabular}

Tabel 6 menunjukan ada peningkatan antara pre test dan post test. Pada pre test persentase peserta didik yang memperoleh nilai $\geq 78$ hanya sejumlah $32,26 \%$ atau 10 anak, sedangkan pada post test meningkat menjadi 80,65\% atau sebanyak 25 anak. Hal ini menunjukan bahwa penerapan pembelajaran Problem Based Learning dapat meningkatkan prestasi belajar dan termasuk dalam kategori tinggi. Sehingga dapat dikatakan berhasil.

3. Refleksi

Beberapa data di atas menunjukan rata-rata skor motivasi dari lembar observasi sebesar 72,78\% dan data dari angket sebesar 83,86\%. Data tersebut menunjukan bahwa ada peningkatan skor dari siklus I ke siklus II, meskipun ada beberapa peserta didik yang masih termasuk dalam peserta didik yang memperoleh 
skor terendah. Pada siklus II ini, skor dapat melampaui kiteria ketuntasan yang diharapkan yakni masuk dalam kategori tinggi (70,01\%-80,00\%) baik pada observasi maupun angket Bagitu pula pada skor peserta didik yang memproleh skor terendah. Pada siklus II, peserta didik yang memperoleh skor terendah lebih sedikit jika dibandingkan dengan siklus I. Pada angket, terdapat 5 peserta didik yang memperoleh skor kurang dari 70,01 \% - 80,00\%. Meski demikian pembelajaran dapat dikatakan meningkatkan motivasi belajar. Sedangkan pada penilaian prestasi belajar, terdapat peningkatan pula dari siklus sebelumnya. Pada siklus ke II ini nilai peserta didik yang $\geq 78$ telah melampaui kriteria yang diharapkan yakni mencapai $80,65 \%$ atau 25 anak pada post test. Hal in menunjukan bahwa hasil test mengalami peningkatan dari siklus sebelumnya. Hal tersebut menunjukan bahwa penerapan pembelajaran ini dapat meningkatkan prestasi belajar peserta didik kelas XII AKL-3. Pelaksanaan pembelajaran pada siklus II ini lebih baik dibandingkan dengan siklus sebelumnya dikarenakan telah dilakukan perbaikan terhadap kekurangan yang terjadi pada siklus I.

Tabel 7. Perbandingan Observasi Motivasi Belajar Siswa Siklus I dan Siklus II

\begin{tabular}{|c|c|c|c|c|}
\hline \multirow[t]{2}{*}{ No } & \multirow{2}{*}{$\begin{array}{c}\text { Indikator } \\
\text { Motivasi Belajar }\end{array}$} & \multicolumn{2}{|c|}{$\begin{array}{c}\text { Persentase skor } \\
\text { motivasi }\end{array}$} & \multirow{2}{*}{$\begin{array}{l}\text { Persentase } \\
\text { peningkatan }\end{array}$} \\
\hline & & Siklus I & Siklus II & \\
\hline 1 & Ketekunan dalam belajar & 60,48 & 71,78 & 11,30 \\
\hline 2 & Ulet menghadapi kesulitan & 62,90 & 73,38 & 10,48 \\
\hline 3 & $\begin{array}{l}\text { Adanya dorongan dan kebutuhan } \\
\text { dalam belajar }\end{array}$ & 62,90 & 72,58 & 9,68 \\
\hline 4 & $\begin{array}{l}\text { Adanya hasrat keinginan untuk } \\
\text { berhasil }\end{array}$ & 60,48 & 73,38 & 12,90 \\
\hline \multicolumn{2}{|c|}{ Jumlah } & 246,76 & 291,12 & 44,36 \\
\hline \multicolumn{2}{|c|}{ Rata- rata skor Motivasi } & 61,69 & 72,78 & 11,09 \\
\hline
\end{tabular}

Tabel 7 menunjukan bahwa terjadi peningkatan rata-rata skor motivasi pada siklus I ke siklus II. Terlihat bahwa terjadi peningkatan pada semua indikator dari siklus I ke siklus II. Berdasarkan data tersebut peningkatan tertinggi ada pada indikator "adanya hasrat keinginan untuk berhasil". Pada saat siklus ke II, peserta didik terlihat lebih bersemangat, karena sebelumnya guru memotivasi peserta didik dan memberi penjelasan tujuan peserta didik mengerjakan tugas baik kelompok maupun mengerjakan soal individu. Sedangkan peningkatan skor terendah ada pada 
indikator "adanya dorongan dan kebutuhan dalam belajar". Hal ini dikarenakan pada saat pembelajaran, peserta didik masih terlihat enggan bertanya ketika ada hal-hal baru yang disampaikan oleh guru karena budaya bertanya yang tidak dibiasakan.

Tabel 8. Perbandingan Angket Motivasi Belajar Siswa Sikuls I dan Siklus II

\begin{tabular}{ccccc}
\hline \multirow{2}{*}{ No } & \multirow{2}{*}{ Kategori } & \multicolumn{2}{c}{ Persentase } & \multirow{2}{*}{ Peningkatan } \\
\cline { 3 - 4 } & & Sikuls I & Siklus II & \\
\hline 1 & Sangat Tinggi & 3,125 & 45,16 & 42,035 \\
2 & Tinggi & 71,875 & 38,70 & $-33,175$ \\
3 & Sedang & 25 & 16,14 & $-8,86$ \\
4 & Rendah & 0 & 0 & 0 \\
5 & Sangat Rendah & 0 & 0 & 0 \\
\hline
\end{tabular}

Pada hasil angket siklus I, motivasi siswa rata-rata masuk pada kategori tinggi dengan persentase $71,875 \%$, artinya peserta didik sudah memiliki motivasi yang cukup tinggi pada saat dilakukan pembagian angket pada siklus I. Meski demikian, yang diharapkan adalah tingkat motivasi yang sangat tinggi dapat terjadi pada peserta didik, mengingat masih ada $25 \%$ peserta didik yang memiliki motivasi cukup rendah. Pada siklus II, terjadi peningkatan presentase motivasi pada peserta didik. Dalam kategori sangat tinggi mengalami peningkatan persentase yang tinggi, naik sebesar $42,035 \%$. Berdasarkan uraian diatas, dapat dilihat bahwa ada peningkatan motivasi belajar dari siklus I ke siklus II sebesar 8,86\% pada kategori tinggi dan sangat tinggi. Baik indikator yang ada pada lembar observasi maupun angket. Sebagian besar indikator yang digunakan pada keduanya sama.

Tabel 9. Perbandingan Nilai Pre Test dan Post test Siklus I dan Siklus II.

\begin{tabular}{ccccccccc}
\hline & \multicolumn{2}{c}{ Siklus I } & \multicolumn{6}{c}{ Siklus II } \\
Kategori & \multicolumn{2}{c}{ Pre Test } & \multicolumn{2}{c}{ Post Test } & \multicolumn{2}{c}{ PreTest } & \multicolumn{2}{c}{ Post Test } \\
nilai & frekuensi & \% & frekuensi & \% & frekuensi & frek & frekuensi & $\%$ \\
\hline Nilai $<78$ & 29 & 93,5 & 11 & 35,5 & 21 & 67,74 & 6 & 19,35 \\
Nilai $\geq 78$ & 2 & 6,5 & 20 & 64,5 & 10 & 32,26 & 25 & 80,65 \\
Jumlah & 31 & 100 & 31 & 100 & 31 & 100 & 31 & 100 \\
Rata-rata & 54,8 & \multicolumn{2}{c}{70,7} & 61,93 & 78,16 \\
\hline
\end{tabular}




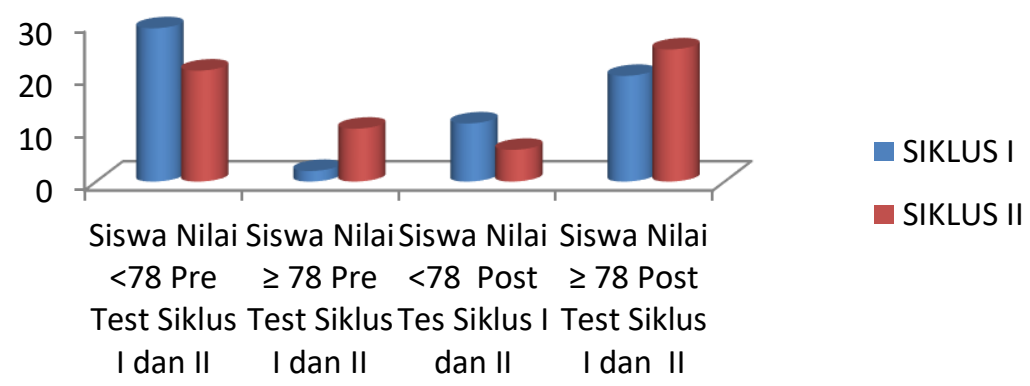

Gambar 2. Grafik Perbandingan Banyak Siswa dengan Nilai Siklus I dan Siklus II.

Tabel 9 dan Gambar 2 menujukkan ada peningkatan nilai rata -rata pre test dan post test baik pada siklus I maupun siklus II. Pada siklus I, rata-rata nilai pre test sebesar 54,8 dengan jumlah peserta didik yang tuntas atau memiliki nilai $\geq 78$ sebanyak 2 peserta didik. Namun terjadi peningkatan setelah dilaksanakan pembelajaran dengan teknik Problem Based Learning yaitu nilai rata-rata post test menjadi 70,7 dan yang meraih nilai $\geq 78$ sebanyak 20 peserta didik. Hal tersebut menunjukan terjadi peningkatan meski belum mencapai kriteria ketuntasan yang diharapkan. Begitu pula pada siklus II, nilai rata-rata siswa mengalami peningkatan dari 61,93 dengan jumlah peserta didik yang tuntas atau memiliki nilai $\geq 78$ sebanyak 10 peserta didik, rata-rata nilai menjadi 78,16 dengan jumlah peserta didik yang tuntas atau memiliki nilai $\geq 78$ sebanyak 25 peserta didik.Pada siklus ke II ini, rata-rata nilai dan jumlah peserta didik yang tuntas KKM sudah memenuhi target yang diharapkan yakni rata-rata nilai mencapai 78,16 dan jumlah peserta didik yang tuntas KKM mencapai 80,65\% dari jumlah peserta didik kelas XII AKL-3. Sehingga dapat dikatakan bahwa pembelajaran teknik Problem Based Learning dapat meningkatkan prestasi belajar matematika peserta didik kelas XII AKL-3.

\section{KESIMPULAN}

Berdasarkan hasil analisis data yang telah dilakukan maka dapat diambil kesimpulan sebagai berikut :

1. Pembelajaran dengan menggunakan model Problem Based Learning pada kelas XII AKL-3 SMK Negeri 2 Purworejo meningkatkan prestasi bejar siswa dilihat dari kenaikan nilai rata-rata pre test dan post test siswa. Rata-rata nilai mencapai 78,16 
dan jumlah peseta didik yang tuntas KKM mencapai 25 siswa atau 80,65\% dari jumlah peserta didik kelas XII AKL-3.

2. Pembelajaran dengan menggunakan model Problem Based Learning pada kelas XII AKL-3 SMK Negeri 2 Purworejo meningkatkan motivasi belajar siswa dilihat dari peningkatan rata- rata skor hasil angket sebesar $8,86 \%$ pada kategori tinggi dan sangat tingi dari siklus I ke Suklus II.

\section{DAFTAR PUSTAKA}

Admin, (2015). Rakornas Pendidikan dan Pembelajaran Sepanjang Hayat Untuk Semua tentang Education for All Development Index (EDI). Diakses melalui www.kemenkopmk.go.id.Pada tanggal 25A gustus 2017.

Amir, M. (2009). Inovasi Pendidikan melalui Problem Based Learning. Jakarta: Perdana Media Group.

Akbar, Sa'dun. (2013). Instrumen Perangkat Pembelajaran. Bandung: Remaja Rosda karya.

Arifin, Zainal. (1991). Evaluasi Instruksional Prinsip Teknik dan Prosedur. Bandung: Remaja Rosda karya.

Arikunto, Suharsini.(2003). Prosedur Penelitian Suatu Praktik. Jakarta: Bina Aksara.

Cahyo, A, N. (2013). Panduan Aplikasi Teori-teori Belajar Mengaja.Jakarta: Raja Grafindo Persada.

Hamdayana, Jumanta. (2014). Model dan Metode Pembelajaran Kreatif. Jakarta: Ghalia Indonesia.

HamzahB. Uno. (2008). Teori Motivasi dan Pengukurannya Analisis Dibidang Pendidikan. Jakarta: Bumi Aksara.

Jauhar, M. (2011). Implementasi Paikem dari Behaviouristik sampai Kontrivistik Sebuah Pengembangan Pembelajaran Berbasis CTL (Contextual Teaching \&Learning. Jakarta: Prestasi Pustakarya.

Lestari, Nyoman Sri. Pengaruh model pembelajran berbasis masalah (Problem Based Learning) dan motivasi belajar terhadap prestasi belajar fisika bagi siswa IPA disekolah dasar. Jurnal Penelitian Pendidikan kelas VII SMP. http://119.252.161.254/ejournal/index.php/jurnal tp/article/view/297/91. Hal $\underline{15 .}$.

Mustaji dan Arthana. (2005) Evaluasi Media Pembelajaran. Unesa Univercity Press.

Maggie Savin dan Claire. (2004). Foundation Of Problem Based Learning. New York: Great Britain. 
Martin dan Handoko. (2001). Motivasi Daya Penggerak TingkahL aku. Jakarta: Rineka Cipta.

Marno, dan M. Idris. (2010). Strategi dan Metode Pengajaran. Jogjakarta: Ar- ruzz Media Group.

Ngalim Purwanto. (2007). Psikologi Pendidikan Remaja.Bandung: Rosda karya.

Purwoko, R. Y. (2017). Urgensi Pedagogical Content Knowledge dalam Meningkatkan Kualitas Pembelajaran Matematika. Jurnal Pendidikan Surya Edukasi (JPSE), 3(2), 42-55.

Purwoko, R. Y., Nugraheni, P., Instanti, D. (2018). Implementation of Pedagogical Content Knowledge Model in Mathematics Learning for High School. Journal of Physics: Conference Series. DOI: 10.1088/1742-6596/1254/1/012079

Sanjaya, W. (2006). Straegi Pembelajaran Berorientasi Standar Proses Pendidikan. Bandung: Alfabetha.

Sansone and Harackiewicz. (2000). Instrinsic an Extrinsic Motivation: The Search for Optimal Motivation and Performance.Academic Press.

Sardiman. (2001). Interaksi dan Motivasi Belajar Mengajar. Jakarta: Rajawali Pers.

Slavin, Robert E. (2009). Cooperative Learning (Teori, Riset, Praktik). Bandung: Nusa Media.

Slameto. (1995). Belajar dan faktor- factor yang mempengaruhinya. Jakarta: Rineka Cipta.

Siregar, E. (2014). Teori Belajar dan Pembelajaran. Bogor: Ghalia Indonesia.

Suparno, Paul. (2010). Filsafat Konstuktivisme Dalam Pendidikan. Yogyakarta: Kanisius.

Sugiyono. (2012). Metode Penelitian Pendidikan: Pendekatan Kuantitatif, Kualitatif, dan R\$D. Bandung: Alfabeta.

Suryabrata, Sumadi. (2005). Pengembangan Alat Ukur Psikologis. Yogyakarta: Andi.

Tan, Oon Seng. (2004). Enchancing Thingkingthrought Problem Based Learning Approaces. Singapore: Thompson Learning.

Trianto. (2009). Mendesain Model Pembelajaran Inovatif- Progresif Konsep, Landasan, dan Implementasinya pada Kurikulum Tingkat Satuan Pendidikan (KTSP). Jakarta: Kencana.

Uno, H. (2008). Model Pembelajaran Menciptakan Proses Belajar Mengajar yang Kreatif dan Efektif. Jakarta Bumi Aksara. 